semi-conductors. His more recent research interests have included work on the bihalide ions, as examples of symmetrically hydrogen-bonded systems, on the chemistry of non-aqueous solvents, particularly hydrogen chloride and sulphide, and on compounds containing 'positive iodine'.

\section{Ministerial Responsibility for Science and Higher Education}

A LetTer dated December 6 from Sir W. Mansfield Cooper, chairman of the Committee of Vice-Chancellors and Principals, to the Prime Minister affirms the support of the overwhelming majority of the Committee for the recommendations of the Robbins Committee regarding ministerial responsibility. The Committee does not, however, favour appointment of a Secretary of State for Education responsible both for the institutes of higher education and for the functions at present exercised by the Minister of Education, and believes that this would prejudice or render impracticable the present close association between the Scottish and the English and Welsh universities and that insufficient weight would be given to the research functions of the universities. The Committee suggests that responsibility for the Research Councils should rest with a minister responsible also for the autonomous institutions of higher education as recommended by the Trend Committee. The Vice. Chancellors Committee recognizes the great importance of adequate co-ordination between all branches of education, but believes that the establishment of the structure of ministerial responsibility advocated by the Robbins Committee is essential.

\section{Teaching of Biology}

The Ministry of Education has agreed to the Royal Society-Institute of Biology Joint Committee being regarded as the National Committee for Britain available for consultation with the Organization for Economic Co-operation and Development over the reform of biology teaching. At the suggestion of the Ministry of Fducation, the Councils of the Royal Society and Institute of Biology have agreed to the addition of two persons to the Committee, one drawn from industry and the other from a university department of education. Dr. F. R. Winton (May and Baker Ltd.) and Dr. Elizabeth Perrott (Department of Education, University of Keele) have accepted invitations to join the Committee. The Joint Committee has appointed two full-time research officers to undertake an investigation of the relations between sixth-form and university biology teaching. The persons appointed are Miss L. M. Lewis-White, who is at prasent employed by the Ministry of Education Research Unit studying programmed learning, and T. S. Robertson, who has experience of teaching at Watford Technical College and, for the past five years, at John Lyon School.

\section{Kennedy "Living Memorial" Project}

FonTy-six Kennedy fellowships, one for each year of the late President John F. Kennedy's life, are to be established at the Weizmann Institute of Science, Israel. They will serve 'as a 'Living Memorial' to the late American President's intense interest in the furtherance of Scientific knowledge for peaceful purposes". The President of the State of Israel, Mr. Zalman Shazar, is to be honorary president of the Israeli Committee for the project, and the Deputy Prime Minister and president of the Weizmann Institute, Mr. Abba Eban, is to be chairman. The first official meeting of the Israeli Committee will be held some time in February. The late President Kennedy had agreed to be guest of honour, and sole speaker, at the eighteenth annual Weizmann dinner, which was to be held by the American Committee for the Weizmann Institute of Science in New York on December 5. With the postponement of the event, after Prosident
Kennedy's assassination, the "Living Memorial" project was announced and President Lyndon B. Johnson agreed to be guest of honour and speaker at the dinner.

Actual contributions and pledges sufficient to cover one-half of the eventual 5-million-dollar endowment fund for the Kennedy fellowships have already been received through the American Committee. It is expected that the $2 \cdot 5$-million-dollar balance will be raised clsewhere in the world, of which 1 million dollars will be sought in Isracl. Twenty-three of the research fellowships are to be assigned to Weizmann Institute scientists and the remainder to scientists from overseas. Each will bo tenable at the Rehovoth research centre for periods of up to two years.

\section{Diploma in Pharmaceutical Analysis}

AfTer discussions which began early in 1962, the Councils of the Pharmaceutical Society of Great Britain and the Royal Institute of Chemistry have agreed to establish a Diploma in Pharmaceutical Analysis. The new Diploma will be awarded to persons who are members of the Society or the Institute and who pass an examination which will require a sound theoretical and practical knowledge of the analytical procedure used in pharmaceutical analysis and of the chemistry and pharmacy on which these are based. Those who enter for the examination must have had comprehensive experience in the analysis of pharmaceutical materials usually of at least five years' duration. A joint examining board appointed by the Society and the Institute will ensure that the award of the Diploma will provide recognition of a high Jevel of competence and understanding in the field of pharmaceutical analysis. The existence of this Diploma, sponsored as it is by two bodies vitally concerned with maintaining and improving the standards of practice in pharmaceutical analysis, should do much to advance the whole subject of the quality control of medicines and pharmaceutical products. Further information can be obtained from the Secretary of either the Pharmaceutical Society of Great Britain, 17 Bloomsbury Square, London. W.C.1, or the Royal Institute of Chemistry, 30 Russell Square, London, W.C.1.

\section{Apartheid in South African Libraries}

A RESOLUTION carried by an overwhelming majority at the October meeting of the Council of the Library Association urged the Library Association of South Africa to reconsider its decision to set up a separate organization for non-European librarians. Besides the Southern Transvaal Branch of the South African Association, the Cape and Natal Branches of that Association have protested. against the Association's decision and, in September, the latter Board tried unsuccessfully to have the whole matter reopened at the Conference held at Pietermaritzburg.

\section{The South African Journal of Science}

The South African Journal of Science for August 1963 contains a tribute to Dr. J. T. Robinson, who is leaving the Transvaal Museum after sixteen years to go as professor of anthropology at the University of Wisconsin. Prof. Robinson is one of the foremost anthropologists in South Africa, and he will certainly have an important part to play in the United States. In the same issue of the Journal there is also a symposium on present-day problems in the behavioural seiences in South Africa. This symposium was originally presented during the Diamond Jubilee Congress of the South Afriean Association for the Advancement of Science in Cape Town in 1962. There are also articles on the industrialization of an indigenous people, and another on some social psychological aspects of economic growth. There is also a contribution to the study of physiological factors in the performance of moderately hard physical work. 